\title{
IS MATTHEW 16:18 AN ANACHRONISM?
}

BY PROF. A. T. ROBERTSON, D. D.

In a recent lecture of Prof. James Drummond, D. D., Principal of Manchester College, Oxford, he argued that Jesus could not have used the words attributed to him in Matt. 16:18, because the ecclesiastical conceptions were too advanced for his time. They were, he said, the addition of a scribe from a later period. This view is held by other scholars also. Leaving out of the question any reference to the divine nature or foreknowledge of Christ and looking at the matter purely from the historical point of view, one can justify the use of the ideas in this passage by the Master. The chief thought here is the perpetuity of the Messianic Kingdom. Now in 2 Sam. 7:8-16 the Kingdom is promised to David forever, through one of his sons, who will build a house for the Lord and whose throne will be set up forever. The

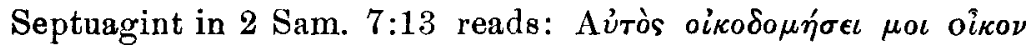

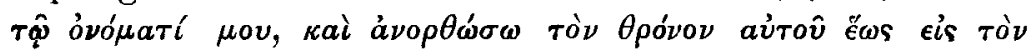
aî๊̄y.

In Psalm 89 ( 88 in the Septuagint) the writer is lamenting the apparent failure of Jehovals to keep this promise. Ho recalls the covenant made with David (Ps. 89:3) in the words of Jehovah: "Thy seed will I establish forever, And build up thy throne to all generations." (Ps. 89:4). The Septua-

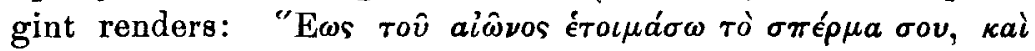

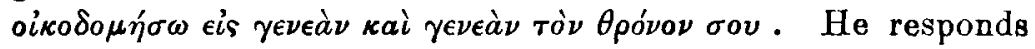
to the words of Jehovah: "And the heavens shall praise thy wonders, $O$ Jehovah; Thy faithfulness also in the assembly of

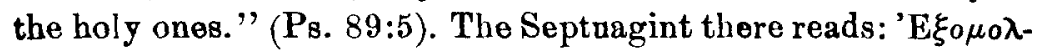

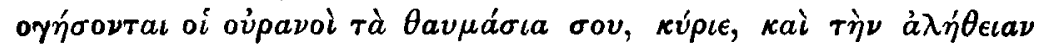

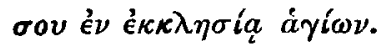

The writer complains, however: "But thou hast cast off and rejected, thou hast been wroth with thine anointed." 


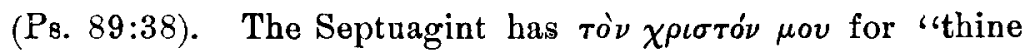
anointed." He knows no man who "shall deliver his soul from the power of Sheol" (Ps. 89:48). The Septuagint has ék $\chi \epsilon \iota \rho)$ 's ádov for "power of Sheol.",

Now it is not claimed that the writer of this Psalm had in mind the spiritual kingdom of tha Messiah. Clearly he was wrestling with the problem of the promise of perpetuity made to the throne of David. But it is remarkable that all the distinctive terms used by Jesus in Matt. 16:18 occur in Psalm 89. The Psalm discusses the perpetuity of David's throne; Jesus discusses the perpetuity of the Messiah's Kingdom. Jesus felt himself to be the Son of David as the Messiah was acknowledged to be (Mark 11:10; Luke 19:40). There was no difference of opinion between Christ and the Pharisees as to whether the Messiah was to be the son of David (Matt. $22: 41-46$ ), but rather as to the character and personality of the Messiah. If it be admitted (for it is a commonplace in the Gospels) that Jesus proclaimed a spiritual kingdom, not a literal, visible kingdom of David (Luke 17:21, for instance), it is surely not straining a point to say that Jesus could see the Messianic application of the promise to David.

Let us then put Matt. 16:18 beside Psalm 89. Jesus said

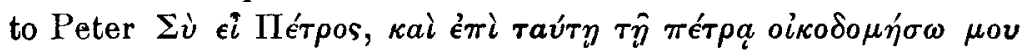

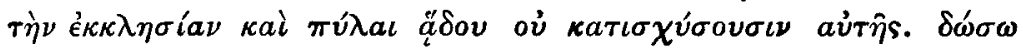

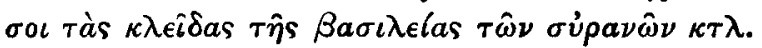

Now in the Psalm (verse 4) we have the figure of building the throne with which compare building the house in $2 \mathrm{Sam}$. $7: 13$. Jesus does not use throne ( $\theta \rho o ́ \nu 0 s)$, but rather é $\kappa \kappa \lambda \eta \sigma l a$

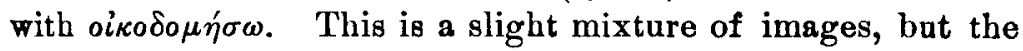
very word $z_{x} \times \lambda$ in ia appears in Ps. 89:5 though not in the precise sense as used by Jesus. In the image of Jesus $\varepsilon \times x \lambda \eta \sigma i a$ is not in the etymological sense of assembly, but rather in the sense of oixos, house of God, people of God, as we have it in Heb. 3:6. Otxws in Numbers 12:7 was used for the people of God in which Moses was a servant. Peter himself (1 Peter 2:5) writing to the Christians of Asia Minor will call them a 


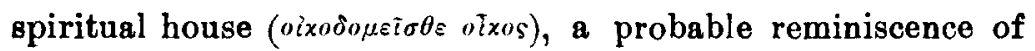
the words of Jesus to him.

'Exxingia thus is a. natural adaptation for the idea of the people of Christ, the Kingdom of Christ as he calls them in Matt. 16:19, the very next verse. It seems clear that Jesus makes no real distinction between $\varepsilon \times x \lambda \eta \sigma i \alpha$ in verse 18 and

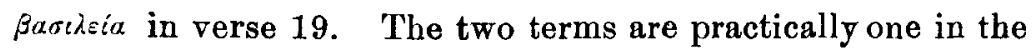
special sense given to each by Christ in this passage.

Peter had called Jesus by the momentous title Messiah, Christ, zpertús. This term is applied to David in this way Psalm 89 (verses 38 and 51). Moreover, Sheol, Hades, occurs

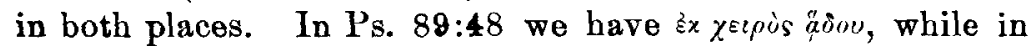

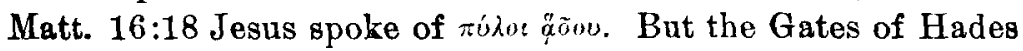
is a common image in ancient Greek and occurs in the Septua-

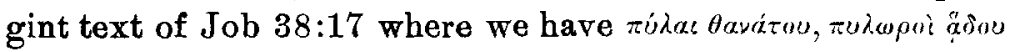

In a word, the historical atmosphere of Matt. 16:18 is not that of a later ecclesiastical development. It finds its most natural and simple explanation in the spiritual interpretation of the idea of the Kingdom of David and many of the very words of Psalm 89, not in the way of literal quotation, but in the apprehension of the Psalm as a whole with the use of the most striking words and images condensed into two short verses.

Christ replies to Peter in the language of Psalm 89 which had been used about the perpetuity of David's throne. David's Greater Son interprets that language in the terms of the Mes sianic Kingdom or Church against which the gates of Hades shall not prevail. This is the sense in which God will keep His promise to David as to the perpetuity of his throne and about which the Psalmist was sore troubled. The historical interpretation of Matt. 16:18, therefore, demands that we look to Christ's knowledge of the Old Testament rather than to a later scribal interpolation as the true setting of the language of these verses. Thus understood the language is not anachronistic, but historically pertinent.

Louisville, $\mathrm{Ky}$. 